\title{
Suffered violence, drug consumption and risk behaviors in homosexual and bisexual individuals
}

कातालm

\begin{abstract}
Grayce Alencar Albuquerque 1,3, Cintia de Lima Garcia1,3, Jameson Moreira Belém², Francisco Winter dos Santos Figueiredo $0^{1,4}$, Laércio da Silva Paiva1,4, Teresa Maria Siqueira Nascimento Arraes ${ }^{3}$, Glauberto da Silva Quirino ${ }^{2}$, Luiz Carlos de Abreu ${ }^{1}$, Vitor Engrácia Valente ${ }^{1}$, Érika da Silva Maciel ${ }^{5}$, Luis Vinicius de Alcantara Sousa ${ }^{1,4}$, Fernando Adami ${ }^{1,4}$
\end{abstract}

\section{Abstract}

Background: This study examined the prevalence of violence suffered, drug use and risk behaviors in homosexual and bisexual individuals.

Method: Cross-sectional, quantitative study involving 296 Lesbian, Gay, Bisexual individuals in the municipalities of Crato and Juazeiro do Norte, South of Ceará state, Brazil.

Findings: Psychological/verbal abuse is the most prevalent and depressants of the central nervous system are chosen for consumption after victimization. Depressant and stimulant drugs were associated to dependence and risk behaviors in sexual minorities.

Conclusion: Gay and bisexual people use drugs after suffering violence, with an association between drug use and developing risk behaviors. Further investigations inherent in these associations are necessary, since other factors may interact to violence, drug use and risk behaviors in sexual minorities.

Keywords

Homosexuality. Bisexuality. Violence. Illicit Drugs
1 Departamento de Saúde da Coletividade, Disciplina de Metodologia Científica, Laboratório de Delineamento de Estudos e Escrita Científica, Faculdade de Medicina do ABC, Santo André, SP, Brasil.

2 Programa de Pós Graduação em Enfermagem. Universidade Regional do Cariri, Crato, CE, Brasil.

3 Curso de Enfermagem. Faculdade de Juazeiro do Norte, Juazeiro do Norte, CE, Brasil.

4 Departamento de Saúde da Coletividade, Laboratório de Delineamento de Estudos e Escrita Científica, Laboratório de Epidemiologia e Análise de Dados, Faculdade de Medicina do ABC, Santo André, SP, Brasil.

5 Centro Universitário Luterano de Palmas CEULP-ULBRA, Palmas, TO, Brasil.

Contact information:

\section{Grayce Alencar Albuquerque}

Tel: (055) (88)88048714

Address: 821. Príncipe de Gales Ave., Príncipe de Gales, Santo André (São Paulo), Brazil.

\section{झ" geycy@oi.com.br}

”' geycyenf.ga@gmail.com

\section{Introduction}

Historically, problems related to the use and abuse of psychoactive substances are more prevalent in sexual minorities [1]. It is known that many factors contribute to the abuse of alcohol and drugs in 
this group [2]. Sexual Minorities resort to drug use to combat stressors, cope with negative feelings associated with social stigma and face homophobia $[3,4,5]$. Individuals who express a homosexual and bisexual orientation are considered abnormal and deviant and, therefore, become exposed to homophobic attacks, expressed in psychological/verbal, physical and sexual ways [6].

In Brazil, homophobia is characterized as a crime $[7,8]$. However, the criminalization of the phenomenon has not reduced the rates of violence against sexual minorities. Data of Gay Group of Bahia show that from 1980 to 2005 about 2,500 gays, transvestites and lesbians were murdered in Brazil, representing, respectively, $72 \%, 25 \%$ and $3 \%$ of all deaths [2]. Data are alarming and give to Brazil the shameful title of homophobic crimes champion [2].

Homophobic acts interact to drug use in Lesbian, Gay, Bisexual, and Transgender (LGBT) people and may reflect attempts to deal with stress and trauma resulting from abuse [1]. There is an association between early start to use and abuse of licit and illicit drugs in homosexuals and bisexuals as a result of physical, emotional and sexual abuse suffered $[9,10]$.

So, violence against the LGBT group is considered a serious public health problem [11]. In addition to causing strong impact on morbidity and mortality in this population, violence is gradually damaging the biopsychosocial health of the group members, who start to manifest negative psychological consequences [12], such as low self-esteem, feelings of loneliness, isolation and depression, which can lead to risk behavior, like suicidal behaviors [13].

Despite the already established relationship between violence, drug use and risk behaviors in sexual minorities, studies that include these variables in the Brazilian homosexual and bisexual population are scarce. Difficulties to obtain data on violence against sexual minorities in Brazil are evident, as these crimes are not always monitored and systematized [14]. The lack of this information makes it difficult to survey epidemiological data on violence suffered, drug use and its consequences in Brazilian LGBT members. The objective was to identify the prevalence of violence suffered, drug use and risk behaviors in a sample of Brazilian homosexual and bisexual individuals.

\section{Method}

This is a cross-sectional, quantitative study, which examined the prevalence of violence suffered, drug use and risk behaviors in homosexual and bisexual peolple.

The study included 296 gay and bisexual individuals who gave their informed consent and answered a structured questionnaire proposed in four blocks: i) socio-economic profile, ii) suffered violence, iii) alcohol and drug consumption and iv) risk behaviors. Data collection was performed during demonstrations (Gay Parade) in the municipalities of Juazeiro do Norte and Crato, state of Ceará, Brazil, in July 2013.

The variables of description of the socioeconomic profile were: biological sex (male and female), gender identity (male and female), sexual orientation (homosexual and bisexual), education (complete/incomplete primary, secondary and higher education), marital status (single, dating, stable, married, divorced and widowed), existence of formal work (yes or no), age (years old) and monthly income (reais).

To identify the occurrence of violence suffered, we adopted the answer criteria "YES" or "NO" to the types of violence: i) psychological/verbal, ii) physical and iii) sexual.

For identification of drug use, we questioned whether the participant had had positive or negative consumption in the last 30 days to: i) alcohol, ii) tobacco, iii) analgesics, iv) marijuana, v) cocaine, vi) tranquillizers, vii) amphetamine viii) ecstasy, ix) hallucinogens, $x$ ) anabolic, xi) and inhalants xii) other psychoactive substances. In order to facilitate the classification of types of drugs consumed by 
mechanism of action within the central nervous system (CNS), it was decided to group them into four groups: i) stimulant drugs, ii) depressant drugs, iii) disturbing drugs and iv) other drugs, regarding those who did not fit in any of the previous three classifications.

The adopted classification followed the recommendations of the French researcher Louis Chaloult, that classified drugs in 1971 into three groups: i) CNS stimulants, ii) CNS depressants and iii) disturbing CNS, which, respectively, accelerate brain function, reduce brain activities and distort the user's perception $[15,16]$. In this classification, regarding the drugs listed in the study, tobacco, painkillers, cocaine/crack and amphetamines are classified as stimulants; alcohol, tranquilizers and inhalants/solvents as depressants; and marijuana, ecstasy and hallucinogens as disturbing. The other drugs category encompassed anabolic and other types consumed.

To identify risk behaviors associated with psychoactive substance use, we asked whether the participants have experienced, under the influence of drugs: i) dependence situations for consumption, ii) health risks to others and iii) risks to their own health. These questions were answered with "YES" or "NO", and the positive responses were equivalent to presence of problems. As a featured risk behavior, we questioned the group about occurrences of suicide attempts, adopting the criterion response "YES" or "NO" to the phenomenon.

The obtained nominal variables were expressed as number of individuals and percentages. We used the chi-square test to analyze the association between nominal variables. The significance level adopted was $95 \%$. The statistical analysis was performed using Stata software version 11.0.

The study was approved by the Research Ethics Committee of the Faculty of Medicine of $A B C$, under the opinion number 472,279.

\section{Results}

\section{Socioeconomic profile of the participants}

Participants were 296 homosexual and bisexual individuals who identified themselves, mostly, with male biological sex (68.6\%), male gender identity (67.6\%), homosexual orientation (78.7\%) median age of 22 years old, predominantly brown (62.2\%), single (62.9\%), with complete High School (33.2\%), no formal work (54.0\%) and median income of 678.00 Brazilian reais (Table 01).

Table 1. Socioeconomic profile of homosexual and bisexual participants in the study. Juazeiro and Crato, Ceará, Brazil, 2013.

\begin{tabular}{|l|c|c|}
\hline \multicolumn{1}{|c|}{ Characteristic } & N & $\%$ \\
\hline Sex & & \\
\hline Male & 203 & 68.6 \\
\hline Female & 93 & 31.4 \\
\hline Identity & & \\
\hline Male & 200 & 67.6 \\
\hline Female & 93 & 31.4 \\
\hline Did not answer & 1 & 0.3 \\
\hline Both identities & 2 & 0.7 \\
\hline Sexual Orientation & & \\
\hline Homosexual & 233 & 78.7 \\
\hline Bisexual & 63 & 21.3 \\
\hline Race & & \\
\hline Yellow & 2 & 0.6 \\
\hline White & 81 & 27.4 \\
\hline Brown & 184 & 62.2 \\
\hline Black & 29 & 9.8 \\
\hline Education & & \\
\hline Complete Elementary Education & 24 & 8,1 \\
\hline Incomplete Elementary Education & 22 & 7.4 \\
\hline Complete Secondary School & 98 & 33.2 \\
\hline Incomplete Secondary School & 69 & 23.3 \\
\hline Complete Higher Education & 27 & 9.1 \\
\hline Incomplete Higher Education & 186.8 \\
\hline Post-graduation & & 14.2 \\
\hline Marital status & 4.7 \\
\hline Single & & \\
\hline Dating & & 62.9 \\
\hline Stable & & 23.3 \\
\hline
\end{tabular}




\begin{tabular}{|c|c|c|c|}
\hline Married & & 11 & 3.7 \\
\hline Divorced & & 1 & 0.3 \\
\hline Widowed & & 2 & 0.7 \\
\hline Did not answer & & 1 & 0.3 \\
\hline \multicolumn{4}{|l|}{ Formal work } \\
\hline No & & 160 & 54.0 \\
\hline Yes & & 129 & 43.6 \\
\hline \multirow[t]{2}{*}{ Did not answer } & & 7 & 2,4 \\
\hline & Median & \multicolumn{2}{|c|}{ Percentile (p.25-p.75) } \\
\hline Income & 678.00 & \multicolumn{2}{|c|}{$500-1.100$} \\
\hline Age & 22 & \multicolumn{2}{|c|}{$19-27$} \\
\hline
\end{tabular}

p. 25 (percentile 25); p.75 (percentile 75).

\section{Violence suffered on sexual orientation}

Among the types of violence suffered (Table 02), there was greater a prevalence of psychological/verbal violence in homosexual and bisexual individuals, totaling 235 victims of such violence (79.3\%), com- pared to other types of violence, such as physical $(n=93,31.4 \%)$ and sexual $(n=57,19.2 \%)$.

\section{Drug use on sexual orientation}

When evaluating the relation between type of violence suffered and sexual orientation and substance use (Table 03), it is observed in homosexual and bisexual individuals increased demand for use of depressants of the central nervous system on victimization by psychological/verbal, physical and sexual violence.

\section{Risk behaviors on violence, drug use and sexual orientation}

As for the consequences of drug use by the study population (Table 04), it appears that CNS stimulants and depressants have a association $(p \leq 0.001)$ bet-

Table 2. Violence suffered as for type of sexual orientation. Juazeiro and Crato, Ceará, Brazil. 2013.

\begin{tabular}{|c|c|c|c|c|c|c|}
\hline \multirow{2}{*}{ Sexual orientation } & \multicolumn{2}{|c|}{ Psychological and verbal } & \multicolumn{2}{|c|}{ Physical } & \multicolumn{2}{|c|}{ Sexual } \\
\hline & $\begin{array}{c}\text { Yes } \\
(235 ; 79.3 \%)\end{array}$ & $\begin{array}{c}\text { No } \\
(61 ; 20.7 \%)\end{array}$ & $\begin{array}{c}\text { Yes } \\
\text { (93; 31.4\%) }\end{array}$ & $\begin{array}{c}\text { No } \\
(203 ; 68.6 \%)\end{array}$ & $\begin{array}{c}\text { Yes } \\
(57 ; 19.2 \%)\end{array}$ & $\begin{array}{c}\text { No } \\
(239 ; 80.8 \%)\end{array}$ \\
\hline Homosexual & $187(80.26)$ & $46(19.74)$ & 74 (31.76) & $159(68.24)$ & 46 (19.74) & $187(80.26)$ \\
\hline Bisexual & $48(76.19)$ & $15(23.81)$ & $19(30.16)$ & $44(69.84)$ & $11(17.46)$ & $52(82.54)$ \\
\hline
\end{tabular}

Table 3. Drug consumption as for type of violence suffered according to sexual orientation. Juazeiro and Crato, Ceará, Brazil. 2013.

\begin{tabular}{|c|c|c|c|c|c|c|c|c|}
\hline \multirow{3}{*}{$\begin{array}{l}\text { Type of } \\
\text { violence }\end{array}$} & \multicolumn{8}{|c|}{ Homosexual/Type of drug } \\
\hline & \multicolumn{2}{|c|}{$\begin{array}{l}\text { Stimulant } \\
\text { (n.\%) }\end{array}$} & \multicolumn{2}{|c|}{$\begin{array}{l}\text { Disturbing } \\
\text { (n.\%) }\end{array}$} & \multicolumn{2}{|c|}{$\begin{array}{c}\text { Depressant } \\
\text { (n.\%) }\end{array}$} & \multicolumn{2}{|c|}{$\begin{array}{l}\text { Others } \\
\text { (n.\%) }\end{array}$} \\
\hline & Yes & No & Yes & No & Yes & No & Yes & No \\
\hline $\begin{array}{l}\text { Psychological } \\
\text { and verbal }\end{array}$ & $62(33.16)$ & $125(66.84)$ & $17(9.09)$ & $170(90.91)$ & $120(64.17)$ & $67(35.83)$ & $33(17.65)$ & $154(82.35)$ \\
\hline Physical & $27(36.49)$ & $47(63.51)$ & $11(14.86)$ & $63(85.14)$ & $49(66.22)$ & $25(33.78)$ & $16(21.62)$ & $58(78.38)$ \\
\hline Sexual & $14(30.43)$ & $32(69.57)$ & $7(15.22)$ & 39 (84.78) & $26(56.52)$ & $20(43.48)$ & $6(13.04)$ & $40(86.96)$ \\
\hline \multirow{3}{*}{$\begin{array}{l}\text { Type of } \\
\text { violence }\end{array}$} & \multicolumn{8}{|c|}{ Bisexual/Type of drug } \\
\hline & \multicolumn{2}{|c|}{$\begin{array}{l}\text { Stimulant } \\
\text { (n.\%) }\end{array}$} & \multicolumn{2}{|c|}{$\begin{array}{l}\text { Disturbing } \\
\text { (n.\%) }\end{array}$} & \multicolumn{2}{|c|}{$\begin{array}{c}\text { Depressant } \\
\text { (n.\%) }\end{array}$} & \multicolumn{2}{|c|}{$\begin{array}{l}\text { Others } \\
\text { (n.\%) }\end{array}$} \\
\hline & Yes & No & Yes & No & Yes & No & Yes & No \\
\hline $\begin{array}{l}\text { Psychological } \\
\text { and verbal }\end{array}$ & $13(27.08)$ & $35(72.92)$ & $11(22.92)$ & $37(77.08)$ & $33(68.75)$ & $15(31.25)$ & $6(12.5)$ & $42(87.5)$ \\
\hline Physical & $8(42.11)$ & $11(57.89)$ & $6(7.14)$ & $13(92.86)$ & $13(68.42)$ & $6(31.58)$ & $2(10.53)$ & $17(89.47)$ \\
\hline Sexual & $3(27.27)$ & $8(72.73)$ & $0(0)$ & $11(100.00)$ & $7(63.64)$ & $4(36.36)$ & $11(100)$ & $0(0)$ \\
\hline
\end{tabular}




\section{INTERNATIONAL ARCHIVES OF MEDICINE \\ Section: Psychiatry \& Mental Health \\ ISSN: 1755-7682}

Table 4. Risk behaviors associated with the type of drug consumed according to sexual orientation. Juazeiro do Norte and Crato, Ceará, Brazil. 2013.

\begin{tabular}{|c|c|c|c|c|c|c|c|c|c|}
\hline \multicolumn{10}{|c|}{ Homosexual } \\
\hline \multirow{3}{*}{$\begin{array}{l}\text { Type of } \\
\text { violence }\end{array}$} & \multicolumn{9}{|c|}{ Consequences of drug use } \\
\hline & \multicolumn{3}{|c|}{ Dependency } & \multicolumn{3}{|c|}{ Risks to health of others } & \multicolumn{3}{|c|}{ Risks to one's own health } \\
\hline & $\begin{array}{c}\text { Yes } \\
\text { n (\%) }\end{array}$ & $\begin{array}{l}\text { No } \\
n(\%)\end{array}$ & $p$-value* & $\begin{array}{c}\text { Yes } \\
\text { n (\%) }\end{array}$ & $\begin{array}{c}\text { No } \\
\text { n (\%) }\end{array}$ & $p$-value* & $\begin{array}{c}\text { Yes } \\
n(\%)\end{array}$ & $\begin{array}{l}\text { No } \\
\text { n (\%) }\end{array}$ & p-value* \\
\hline Stimulant & $49(64.47)$ & $27(35.53)$ & $<0.001$ & $49(64.47)$ & $27(35.53)$ & $<0.001$ & $61(80.26)$ & 15 (19.74) & $<0.001$ \\
\hline Depressant & $85(57.43)$ & $63(42.57)$ & $<0.001$ & $80(54.05)$ & $68(45.95)$ & $<0.001$ & $112(75.68)$ & $36(24.32)$ & $<0.001$ \\
\hline Disturbing & $10(52.63)$ & $9(47.37)$ & 0.417 & $13(68.42)$ & $6(31.58)$ & 0.007 & $16(84.21)$ & $3(15.79)$ & 0.009 \\
\hline Others & $25(64.1)$ & $14(35.9)$ & 0.005 & $23(58.97)$ & $16(41.03)$ & 0.006 & $29(74.36)$ & $10(25.64)$ & 0.011 \\
\hline \multicolumn{10}{|c|}{ Bisexual } \\
\hline \multicolumn{10}{|c|}{ Consequences of drug use } \\
\hline \multirow{2}{*}{$\begin{array}{l}\text { Type of } \\
\text { drug }\end{array}$} & \multicolumn{3}{|c|}{ Dependency } & \multicolumn{3}{|c|}{ Risks to health of others } & \multicolumn{3}{|c|}{ Risks to one's own health } \\
\hline & $\begin{array}{c}\text { Yes } \\
\text { n (\%) }\end{array}$ & $\begin{array}{c}\text { No } \\
n(\%)\end{array}$ & p-value* & $\begin{array}{c}\text { Yes } \\
\text { n (\%) }\end{array}$ & $\begin{array}{c}\text { No } \\
n(\%)\end{array}$ & $p$-value* & $\begin{array}{c}\text { Yes } \\
\text { n (\%) }\end{array}$ & $\begin{array}{c}\text { No } \\
n(\%)\end{array}$ & p-value* \\
\hline Stimulant & $13(61.9)$ & $8(38.1)$ & 0.212 & $9(42.86)$ & $12(57.14)$ & 0.856 & $16(76.19)$ & $5(23.81)$ & 0.257 \\
\hline Depressant & $28(60.87)$ & $18(39.13)$ & 0.009 & $24(52.17)$ & $22(47.83)$ & 0.004 & $38(82.61)$ & $8(17.39)$ & $<0.001$ \\
\hline Disturbing & $11(73.33)$ & $4(26.67)$ & 0.045 & $7(46.67)$ & $8(53.33)$ & 0.627 & 13 (86.67) & $2(13.33)$ & 0.060 \\
\hline Others & $3(50)$ & $3(50)$ & 0.967 & $2(33.33)$ & $4(66.67)$ & 0.678 & $3(50)$ & $3(50)$ & 0.363 \\
\hline
\end{tabular}

* Probable values of the chi-square test, with a significance level of $p \leq 0.05$.

ween homosexual individuals to dependence and risk behaviors to their own health and the health of others. Among bisexual individuals, depressant drugs had association as the three types of injuries of harms, respectively, for dependency ( $p=0.009$ ), risks to others' health $(p=0.004)$ and risk to their own health ( $p=\leq 0.001)$.

As for risk behavior to one's own health, suicide attempts were associated with the type of drug consumed only in the homosexual population (Table 05). In this group, a positive association was obtained between consuming CNS disturbing drugs and attempting suicide $(p<0.001)$.

\section{Discussion}

To our knowledge, this is the first study conducted in Brazil that sought to examine the association between sexual orientation, suffered violence, drug use and risk behaviors in a sample of homosexual and bisexual individuals.
Table 5. Suicide attempts as for type of drug consumed according to sexual orientation. Juazeiro and Crato, Ceará, Brazil. 2013.

\begin{tabular}{|c|c|c|c|}
\hline \multicolumn{4}{|c|}{ Homosexual } \\
\hline \multirow[b]{2}{*}{ Type of drug } & \multicolumn{3}{|c|}{ Suicide attempt } \\
\hline & $\begin{array}{c}\text { Yes } \\
\text { n (\%) }\end{array}$ & $\begin{array}{c}\text { No } \\
\text { n (\%) }\end{array}$ & $p$-value* \\
\hline Stimulant & $16(25)$ & $48(75)$ & 0.047 \\
\hline Depressant & $27(22.88)$ & 91(77.12) & 0.009 \\
\hline Disturbing & $9(56.25)$ & 7(43.75) & $<0.001$ \\
\hline Others & $5(14.29)$ & $30(85.71)$ & 0.590 \\
\hline \multicolumn{4}{|c|}{ Bisexual } \\
\hline \multirow[b]{2}{*}{ Type of drug } & \multicolumn{3}{|c|}{ Suicide attempt } \\
\hline & $\begin{array}{c}\text { Yes } \\
\text { n (\%) }\end{array}$ & $\begin{array}{c}\text { No } \\
\text { n (\%) }\end{array}$ & p-value* \\
\hline Stimulant & $6(35.29)$ & $11(78.85)$ & 0.082 \\
\hline Depressant & $9(23.08)$ & $30(76.92)$ & 0.556 \\
\hline Disturbing & 4(36.36) & 7(63.64) & 0.164 \\
\hline Others & 2(33.33) & $4(66.67)$ & 0.437 \\
\hline
\end{tabular}

* Probable values of the chi-square test, with a significance level of $p \leq 0.05$. 
By analyzing the variables studied, it was observed that: i) psychological/verbal violence is the most prevalent in homosexual and bisexual individuals ii) CNS depressive drugs emerge as a top choice for consumption in homosexual and bisexual people due to the violence suffered, iii) depressant and stimulant drugs showed a stronger association for addiction, risks to others' health and their own health in homosexual individuals, iv) depressant drugs were associated with risk behavior in bisexual individuals v) disturbing, stimulant and depressant drugs were associated with suicide attempts in homosexual individuals.

Scientific evidence has revealed that sexual minorities have high risk for disorders related to psychoactive substance abuse [17, 18, 19], being more prone to early experimentation, risk behaviors associated with the use, higher rates of abuse/dependence, susceptibility to relapse and difficulties to refrain from the use [1].

Despite evidence in sexual minorities, it is important to emphasize drug use on sexual orientation beyond the homosexual and heterosexual traditional division. Recent research has begun to introduce and examine the bisexual sexual orientation in this context [2]. Several studies have found that women and bisexual men are also likely to report alcohol and other drugs abuse when compared to exclusive heterosexual and homosexual people [20, 21, 22, 23].

It is believed that the abuse of psychoactive substances by homosexual and bisexual individuals, although it is a unique and individualized process, appears to be linked to the group as a way to deal with several negative feelings, among them, the insecurity and anxiety about their own acceptance of sexual orientation [24], even to cope situations of violence [25], as a result of homophobia.

Violent experiences arise frequently and are part of the day-to-day of homosexual and bisexual population. Study with 526 homosexuals living in Los Angeles showed that $98 \%$ of the sample reported having experienced homophobic acts, expressed in the form of emotional abuse, physical and sexual assaults [5], corroborating the data found in this research, in which all participants of the sample have experienced at least one homophobic act in life, especially emotional abuse.

In Brazil, survey based on data from Disque Direitos Humanos-Dial Human Rights (Disque 100-Dial 100) Human Rights Department of the Republic Presidency [26] revealed that of the 6,809 human rights violations recorded against sexual minorities, involving 1,713 victims, psychological violence was the most reported, representing $42.5 \%$ of the total, followed by discrimination, with $22.3 \%$ and physical violence, with $15.9 \%$ of all reported violations.

Since it is more prevalent, psychological suffering of homosexual and bisexual people is significantly associated with increased drug use, for it is configured as coping strategies to negative thoughts that affect the mental health of sexual minorities as a consequence of victimization [27, 28].

In this sense, it is inferred that the prevalence for consumption of CNS depressive drugs in bisexual and homosexual participants of this study is related to the mechanism of action of these substances. These drugs, by reducing brain activity and depressing its operation [15], act as escape valves to cope with situations of violence, allowing the victim to become 'off', 'careless' and 'decentralized' [29], preventing them to strike back violent acts and, therefore, the persistence of negative thoughts associated with the phenomenon.

Study with 594 individuals living in Los Angeles and New York, from 2009 to 2011, in which 201 (34\%) declared being gay, revealed that in the entry model for using CNS depressants, such as tranquilizers drugs, interaction between emotional abuse and homosexual orientation was significant ( $p$ $<0.05$ ) [30]. These data corroborate those found in this study, in which the use of CNS depressant drugs remained the preferred drugs for use in cases of violence, especially emotional abuse, regardless of sexual orientation. 
Although used in face of suffered violence, constant consumption of psychoactive substances can cause adverse effects, increasing the susceptibility of homosexual and bisexuals individuals to occurrence of disorders, among these, dependency and risk behaviors. Evidence suggests that individuals who identify themselves as lesbian, gay or bisexual generally have higher chances for psychoactive substances than heterosexual people [19].

In this sample, homosexual subjects had greater association between consuming CNS stimulants and depressants and evolving with signs of dependence and risk behaviors of their own health and that of others. In bisexual individuals, the strength of association remained for depressant drugs.

Scientific evidence have indicated that the main risk behaviors consequent to the use of drugs in sexual minorities are unsafe sexual practices [31], memory problems associated with post-consumption [32] and wishes to use, resulting in signs of addiction [33].

Dependence to drug use appears to be associated with the mechanism of action of psychoactive substances, especially, those that arouse feelings of joy, euphoria and well-being (CNS stimulant drugs) and tranquility and shutdown of reality (CNS depressant drugs). The sense of pleasure and tranquility obtained with the use of these psychoactive substances increases the potential for dependence, increasing the chances of developing psychiatric comorbidities such as depressive, anxiety and personality disorders [34] and that result in greater health risks of sexual minorities, like the suicidal behaviors [18].

In this sense, it is observed that as a result of suffered violence and drug use, sexual minorities have susceptibility to mental health disorders and increased chances for suicide ideation and attempts. The relation between psychiatric comorbidities and suicide attempts is already established in the literature [35]. Suicidal behavior in homosexual and bisexual subjects is a result of internalizing and externalizing mental health disorders [35, 36, 37], consequent to the social stigma, violence and discrimination [18].
Thus, violence based on sexual orientation implies profound impact on the mental health of LGBT members. Study with minority sexual orientation young people who have experienced high levels of violence were likely to report depression and to attempt suicide than those who experienced lower levels [38].

In addition to violence, the use of psychoactive substances is strong stressor for the mental health of LGBT members, resulting in suicidal behaviors [39]. In our study, homosexual individuals who used the three types of drugs (CNS disturbing) showed association to suicide attempts for the disturbing drugs, since they, in their mechanism of action, act disrupting the CNS functioning, by causing delusions and hallucinations $[15,16]$, increasing the chances for suicide ideation and attempts. In fact, CNS disturbing drugs, such as ecstasy, present greater association for suicide attempts than other types of drugs.

Although important, study findings have some limitations. These data do not allow deepening in face of the multi-causal conditions that can interact for the occurrence of violence against sexual minorities, for drug use and adoption of risk behaviors. With these limitations in mind, it is difficult to generalize the results for all homosexual and bisexual people. Thus, further analysis of these conditions should be investigated.

Despite the limitations, this study provides directions, as it reinforces the alert to the involvement of homosexual and bisexual subjects in violence and drug use. It is evident that this population presents more chances to damage and health problems, which reveals the need to (re) formulate public policies that address protection and citizenship to this group, allowing them to fully exercise their rights as citizens.

\section{Contribuintes}

Grayce Alencar Albuquerque is the principal investigator on the study and contributed to a substantial 
portion of the writing and interpretation of results for this paper.

Cintia de Lima Garcia conducted a significant portion of the background research for this paper and also contributed to writing.

Jameson Moreira Belém conducted a significant portion of the background research for this paper and also contributed to writing.

Francisco Winter dos Santos Figueiredo conducted a significant portion of the background research for this paper and also contributed to writing.

Laércio da Silva conducted a significant portion of the background research for this paper and also contributed to writing.

Teresa Maria Siqueira Nascimento Arrais participated in interpretation of the results and writing the final manuscript.

Glaubero da Silva Quirino participated in interpretation of the results and writing the final manuscript.

Luiz Carlos de Abreu participated in interpretation manuscript of the results and writing the final manuscript.

Érika da Silva Maciel participated in interpretation of the results and writing the final manuscript.

Luiz Vinicius de Alcantara Sousa participated in interpretation of the results and writing the final manuscript.

Vitor Engrácia Valenti participated in interpretation of the results and writing the final manuscript.

Fernando Adami contributed to this paper through conceptualization, data analysis and writing.

All authors have reviewed and approved the final manuscript.

\section{Conflict of interests}

The authors declare that there are no conflicts of interest.

\section{Financial support}

This study received no funding.

\section{References}

1. Diehl A. Abuso e dependência de substâncias psicoativas em homossexuais e bissexuais: revisão da literatura. [Monograph]. Faculdade de Medicina da Universidade de São Paulo. Instituto e Departamento de Psiquiatria do Hospital das Clínicas. 2009. São Paulo: SP.

2. Green KE., Feinsten BA. Substance Use in Lesbian, Gay, and Bisexual Populations: An Update on Empirical Research and Implications for Treatment. Psychology Addictive Behavior. 2012; 26 (2): 265-278. doi.: 10.1037/a0025424 Available at http://www.ncbi.nlm.nih.gov/pmc/articles/PMC3288601/

3. Meyer IH. Prejudice, Social Stress, and Mental Health in Lesbian, Gay, and Bisexual Populations: Conceptual Issues and Research Evidence. Psychologycal Bulletin. 2003; 129 (5): 674-697. doi.: 10.1037/0033-2909.129.5.674 Available at http://www.ncbi. nlm.nih.gov/pmc/articles/PMC2072932/

4. Marshal MP, Burton CM, Chisolm DJ, Sucato GS, Friedman MS. Cross-sectional evidence for a stress-negative affect pathway to substance use among sexual minority girls. Clinical and Translational Science. 2013; 6: 321-322. doi: 10,1111/cts.12052 Available at: http://www.ncbi.nlm.nih.gov/pmc/articles/ PMC3740447/

5. Wong CF, Weiss G, Ayala G, Kipke MD. Harassment, discrimination, violence and illicit drug use among men young men who have sex with men. AIDS Education and Prevention: official publication of the International Society for AIDS Education. 2010; 22 (4): 286-98. doi.: 10,1521/ aeap.2010.22.4.286. Available at http://www.ncbi.nlm.nih.gov/ pmc/articles/PMC2962624/

6. Ramos S, Carrara S. A Constituição da Problemática da Violência contra Homossexuais: a Articulação entre Ativismo e Academia na Elaboração de Políticas Públicas. PHYSYS: Revista de Saúde Coletiva. 2006; 12(2): 185-205. doi.: 10.1590/S010373312006000200004. Available at http://www.scielo.br/pdf/ physis/v16n2/v16n2a04.pdf

7. Cardoso MR, Ferro LF. Saúde e população LGBT: demandas e especificidades em questão. Psicologia Ciência e Profissão. 2012; 32 (3): 552-563. doi.: 10.1590/\$1414-98932012000300003. Available at http://www.scielo.br/scielo.php?script=sci_arttext\&pid=S141498932012000300003\&lng=pt\&nrm=iso\&tlng=en

8. Brasil, MS. Brasil sem homofobia. Programa de combate à violência e à discriminação contra GLBT e da promoção da cidadania homossexual. Ministério da Saúde. Conselho Nacional de Combate à Discriminação. Brasília, DF. Available at: http://www. bvsms.saude.gov.br/bvs/publicacoes/brasil_sem_homofobia.pdf

9. Ompad DC, Ikeda RM, Shah N, Fuller CM, Bailey S, Morse E, Kerndt E, Maslow C, Wu Y, Vlahov D, Garfein R, Strathdee S. Childhood Sexual Abuse and Age at Initiation of Injection Drug Use. American Journal of Public Health. 2005; 95(4):703-9. doi.: 10.2105/AJPH.2003.019372 Available at http://www.ncbi.nlm. nih.gov/pmc/articles/PMC1449244/?report=reader 
10. Roy E, Haley N, Leclerc P, Cédras L, Blais L, Boivin JF. Drug injection among street youths in montreal: Predictors of initiation. Journal of Urban Health. 2003; 80 (1): 92 105. doi.: 10.1093/jurban/jtg092 Available at http://www.ncbi.nlm.nih. gov/pmc/articles/PMC3456111/pdf/11524_2006_Article_174. pdf

11. Pelullo CP, Di Giuseppe G, Angelillo IF. Frequency of discrimination, harassment, and violence in lesbian, gay men, and bisexual in Italy. PloS One. 2013; 8 (8): e74446. doi.: 10.1371/journal.pone.0074446. Available at http://www.ncbi. nlm.nih.gov/pmc/articles/PMC3749994/\#B7

12. Hatzenbuehler ML, Wieringa NF, Keyes KM. Community-level determinants of tobacco use disparities in lesbian, gay, and bisexual youth: results from a population-based study. Archives of Pediatrics \& Adolescent Medicine. 2011; 165: 527-532. doi: 10.1001/archpediatrics.2011.64. Available at: http://archpedi. jamanetwork.com/article.aspx?articleid=384709

13. Traube DE, Holloway IW, Schrager SM, Kipke MD. Utilizing Social Action Theory as a framework to determine correlates of illicit drug use among young men who have sex with men. Psychology of Addictive Behavior. 2012; 26: 78-88. doi.: 10.1037/a0024191. Available at: http://www.ncbi.nlm.nih.gov/ pmc/articles/PMC3241957/

14. Mott L, Cerqueira M. Causa mortis: homofobia. Violação de direitos humanos e assassinato de homossexuais no Brasil. Editora Grupo Gay da Bahia. 2000. Salvador- BA.

15. Santos CB. É proibido fumar, diz o aviso que eu li": o serviço social na promoção da saúde do usuário tabagista. [Monograph]. Pontifícia Universidade Católica do Rio Grande do Sul. Faculdade de Serviço Social. 2014. Porto Alegre, Rio Grande do Sul. Available at http://revistaseletronicas.pucrs.br/ojs/index. php/graduacao/article/viewFile/15528/1016.

16. Monteiro RMP. Álcool e outras drogas: diálogos sobre um mal estar contemporâneo. Cadernos de Saúde Pública. 2013; 29 (8): 1693-1694. doi.: 10.1590/0102-311XRE020813. Available at http://www.scielo.br/scielo.php?script=sci_arttext\&pid=S0102$311 \times 2013000800024 \&$ lng =pt\&nrm=iso\&tlng=en

17. Cochran SD, Mays VM, Alegria M, Ortega AN, Takeuchi D. Mental health and substance use disorders among Latino and Asian American lesbian, gay, and bisexual adults. Journal of Consulting and Clinical Psychology. 2007; 75 (5): 785-794. doi.: 10.1037/0022-006X.75.5.785 Available at http://www.ncbi. nlm.nih.gov/pmc/articles/PMC2676845/

18. King M, Semlyen J, Tai VS, Killaspy H, Osborn D, Popelyuk D, Nazareth I. A systematic review of mental disorder, suicide and deliberate self-harm in lesbian, gay and bisexual people. BMC Psychiatry. 2008; 8(70): 1333-1345. doi.: 10.1186/1471-244X8-70. Available at http://www.ncbi.nlm.nih.gov/pmc/articles/ PMC2533652/
19. McCabe SE, Bostiwick WB, Hughes $T L$, West BT, Boyd $C J$. The Relationship Between Discrimination and Substance Use Disorders Among Lesbian, Gay, and Bisexual Adults in the United States. American Journal of Public Health. 2010; 100 (10): $1946-$ 52. doi.: 10.2105/AJPH.2009.163147. Available at http://www. ncbi.nlm.nih.gov/pmc/articles/PMC2937001/\#!po=6.52174

20. For JA, Jasinski JL. Sexual orientation and substance use among college students. Addictive Behavior. 2006; 31(3): 404-13. doi.: 10.1016/j.addbeh.2005.05.019. Available at: http://webcache.googleusercontent.com/search?q=cache:yyzsBbfFF4J:www.researchgate.net/profile/Jason_Ford2/ publication/7773810_Sexual_orientation_and_substance_use_ among_college_students/links/0deec527bb5d09252f000000. $p d f+\& c d=3 \& h l=p t-B R \& c t=c \mid n k \& g l=b r$

21. McCabe SE, Hughes TL, Bostwick WB, West BT, Boyd CJ. Sexual orientation, substance use behaviors and substance dependence in the United States. Addiction. 2009; 104(8): 1333-1345. doi:10.1111/j.1360-0443.2009.02596.x. Available at: http://www. ncbi.nlm.nih.gov/pmc/articles/PMC2975030/?report=reader

22. Tucker JS, Ellickson PL, Klein DJ. Understanding differences in substance use among bisexual and heterosexual young women. Womens Health Issues. 2008; 18(5): 387-98.doi.: 10.1016/j. whi.2008.04.004

23. Wilsnack SC, Hughes TL, Johnson TP, Bostwick WB, Szalacha LA, Benson P, Aranda, F, Kinnison KE. Drinking and drinkingrelated problems among heterosexual and sexual minority women. Journal of Studies on Alcohol and Drugs. 2008; 69(1): 129-39

24. Dearing RL, Hequembourg AL. Exploring shame, guilt, and risky substance use among sexual minority men and women. Journal of Homosexuality. 2013; 60 (4): 615-638. doi.: 10.1080/00918369.2013.760365. Available at http://www. ncbi.nlm.nih.gov/pmc/articles/PMC3621125/

25. Reed E, Padro G, Amaro H. Alcohol and drug use and related consequences among gay, lesbian and bisexual college students: role of experiencing violence, feeling safe on campus, and perceived stress. Addict Behaviors. 2010; 35: 168-171. doi.: 10.1016/j.addbeh.2009.09.005. Available at: http://www.ncbi. nlm.nih.gov/pmc/articles/PMC2783782/

26. Brasil MS. Secretaria de Direitos Humanos. Relatório sobre violência homofóbica no Brasil: ano de 2011. Secretaria de Direitos Humanos. 2011. Brasília, DF. Available at http://www. sdh.gov.br/assuntos/lgbt/pdf/relatorio-violencia-homofobicaano-2012

27. Dudley MG, Rostosky SS, Korfhage BA, Zimmerman RS. Correlates of high-risk sexual behavior among young men who have sex with men. AIDS Education and Prevention: official publication of the International Society for AIDS Education. 2013; 16(4): 328-40. doi.: 10.1521/aeap.16.4.328.40397 
28. Rosario M, Schrimshaw EW, Hunter J, Levy-Warren A. The coming out process of young lesbian and bisexual women: are there butch/femme differents in sexual identity development? Archives of Sexual Behavior. 2009; 38: 34-49. Available at: http:// www.ncbi.nlm.nih.gov/pmc/articles/PMC3189348/

29. Sengike SA, Scortegagna SA. Consumo de drogas psicoativas em adolescentes escolares. Psic: Periódicos Eletrônicos em Psicologia. 2008; 9(1): 73-80. Available at http://pepsic.bvsalud. org/scielo. php?pid=\$167673142008000100009\&script=sci_ arttext

30. Kekojevic A, Wong CF, Lankenau SE. Initiation into Prescription Drug Misuse: Differences between Lesbian, Gay, Bisexual, Transgender (LGBT) and Heterosexual High-Risk Young Adults in Los Angeles and New York. Addictive Behavior. 2012; 37 (11): 1289-1293. doi.: 10.1016/j.addbeh.2012.06.006. Available at http://www.ncbi.nlm.nih.gov/pmc/articles/PMC3409829/

31. Solomon TM, Halkitis PN, Barton SC. Sex parties among young gay, bisexual and other men who have sex with men in New York city: Attendance and behavior. Journal of Urban Health. 2011; 88 (6): 1063-75. doi.: 10,1007/s11524-011-9590-5. Available at http://www.ncbi.nlm.nih.gov/pmc/articles/PMC3232420/

32. Vieira NA. Entendendo quem entende: comportamentos, atitudes e práticas de risco e de prevenção para aids entre homens que fazem sexo com homens. [Dissertation]. Fundação Oswaldo Cruz. Centro de Pesquisas Aggeu Magalhães. Departamento de Saúde Coletiva. 2006. Recife: PE.

33. Hughes TL, Jonhson TP, Szalacha LA. Childhood risk factors for alcohol abuse and psychological distress among adult lesbian. Child Abus \& Neglect. 2007; 31 (7): 769-89. doi.: 10.1016/j. chiabu.2006.12.014. Available at http://www.ncbi.nlm.nih.gov/ pmc/articles/PMC2600503/

34. Hess ARB, Almeida RMM, Moraes AL. Comorbidades psiquiátricas em dependentes químicos em abstinência em ambiente protegido.EstudosdePsicologia. 2012;17(1):171-178. doi.: 10.1590/ S1413-294X2012000100021. Available at http://www.scielo.br/ scielo. php?pid=S1413-294X2012000100021\&script=sci_arttext

35. Haas AP, Eliason M, Mays VM, Mathy RM, Cochran SD, D'Augelli AR, Silverman MM, Fisher PW, Hughes T, Rosario M, Russell ST, Malley E., Reed J, Litts DA, Haller E, Vender RL, Remafedi G, Bradford J, Beautrais AL, Brown GK, Diamante GM, Friedman MS, Gaforalo R, Turner MS, Hollibaugh A,Clayton PJ. Suicide and SuicideRiskin Lesbian, Gay, Bisexual, and TransgenderPopulations: Review and Recommendations. Journal of Homosexuality. 2011; 58(1): 10-51. doi.: 10.1080/00918369.2011.534038. Available at http://www.ncbi.nlm.nih.gov/pmc/articles/PMC3662085/

36. Conron KJ, Mimiaga MJ, Landers SJ. A population-based study of sexual orientation identity and gender differences in adult health. American Journal of Public Health. 2010; 100 (10): 19531960. doi.: 10.2105/AJPH.2009.174169. Available at http://www. ncbi.nlm.nih.gov/pmc/articles/PMC2936979/?report=reader
37. Mustanski BS, Garofalo R, Emerson EM. Mental Health Disorders, Psychological Distress, and Suicidality in a Diverse Sample of Lesbian, Gay, Bisexual, and Transgender Youths. American Journal of Public Health. 100 (12): 2426-32. doi.: 10.2105/AJPH.2009.178319. Available at http://www.ncbi.nlm. nih.gov/pmc/articles/PMC2978194/

38. Russell ST, Ryan C, Toomey RB, Diaz RM, Sanchez J. Lesbian, gay, bisexual, and transgender adolescent school victimization: Implications for young adult health and adjustment. Journal of School Health. 2011; 81 (5): 223-230. doi.: 10.1111/j.17461561.2011.00583.x.

39. O'Donnel S, Meyer IH, Schwartz S. Increased risk of suicide attempts among black and latino lesbian, gay men, and bisexual. American Journal of Public Health. 2011; 101 (6): 1055-59. doi.: 10.2105/AJPH.2010.300032. Available at http://www.ncbi.nIm. nih.gov/pmc/articles/PMC3093285/\#!po=12.5000

\section{Comment on this article:}

\section{(f) 8 in $8+\boldsymbol{S} P$}

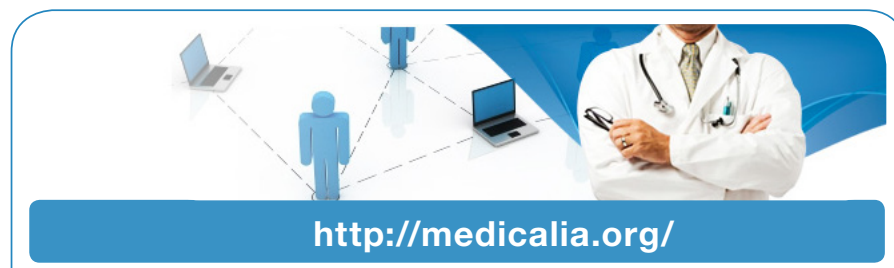

Where Doctors exchange clinical experiences, review their cases and share clinical knowledge. You can also access lots of medical publications for free. Join Now!

\section{Publish with iMedPub}

\section{http://www.imed.pub}

International Archives of Medicine is an open access journal publishing articles encompassing all aspects of medical science and clinical practice. IAM is considered a megajournal with independent sections on all areas of medicine. IAM is a really international journal with authors and board members from all around the world. The journal is widely indexed and classified Q1 in category Medicine. 